\title{
Pluralisme Agama dalam Pandangan Abdul Mukti Ali
}

\author{
M. Abizar \\ Mahasiswa Magister UIN Sunan Kalijaga Yogyakarta \\ abizar2095@gmail.com
}

\begin{abstract}
Mukti Ali has been called the father of religion, because be was the minister of the religious of the Indonesian republic and was deeply plural in mind. For him it is a fact, that we are different, diverse and pluralistic in religion and this is a social reality, something that is abject and undeniable. In the Abdul Mukti Ali concept, there are three things that are critical to social, social, and religious life. First, it is important to maintain harmony among the same religious people. Second, the importance of maintaining harmony between people of different religions. Because in history, religious conflicts anywhere in the world have been fought, and this country is no exception. Third, the importance of building religious relations with governments, so that religious life can be carried out ina sense of peace and security. Next on this Abdul Mukti Ali accepts one aspect of the offered aspects of religious life, which is the defining aspect of which is in agreement with distinction, "as abdul mukti ali says in this respect that religious believers can be united, appreciate and respect in political prosperity, especially in religious relations
\end{abstract}

\section{Keyword: Mukti Ali, Pluralism, Religion}

Abstrak. Mukti Ali disebut sebagai bapak agama, karena beliau adalah tokoh cendekiawan muslim Indonesia yang pernah menjabat sebagai menteri agama Republik Indonesia, selain itu pemikiran beliau sangat Plural dan sangat menerima perbedaan. Baginya adalah sebuah kenyataan, bahwa kita adalah berbeda-beda, beragam dan plural dalam beragama dan ini adalah kenyataan sosial, sesuatu yang niscaya dan tidak dapat dipungkiri lagi. Dalam konsep pemikiran Abdul Mukti Ali ada tiga hal yang sangat penting diketahui untuk kehidupan sosial, bermasyarakat, dan beragama yaitu: Pertama, pentingnya menjaga kerukunan antar umat seagama. Kedua, pentingnya menjaga kerukunan antar umat berbeda agama. karena dalam sejarah, konflik agama di belahan dunia manapun pernah terjadi, tak terkecuali di negeri kita ini. Ketiga, pentingnya membina hubungan umat beragama dengan pemerintah, agar kehidupan beragama dapat dilaksanakan dengan perasaan damai dan terjamin. Seterusnya Abdul Mukti Ali menerima satu aspek dari beberapa aspek yang ditawarkan dalam kehidupan beragama, yaitu aspek Agree in disagreement yang maksudnya adalah "Setuju dalam Perbedaan", karena menurut Abdul Mukti Ali dalam aspek inilah umat beragama bisa rukun, 
saling menghargai dan menghormati dalam bermasyarakat, berpolitik, terutama hubungan antar umat beragama.

\section{Kata Kunci : Mukti Ali, Pluralisme, Agama}

\section{PENDAHULUAN}

Sejarah agama besar dunia yang masih eksis keberadaannya dan masih ada pemeluknya sampai saat ini, adalah agama Hindu, agama Yahudi, agama Zaroaster, agama Shinto, agama Tao, agama Jaina, agama Buddha, agama Konghuchu, agama Kristen, dan agama Islam. Semua agama itu mempunyai kitab suci, mempunyai nabi, mempunyai tempat ibadah, serta meyakini adanya Tuhan dan kehidupan di akhirat (Mansur, 2018) Pluralisme agama adalah sebuah perkembangan lebih jauh dari inklusivisme dengan pengakuan adanya kebenaran dalam tradisi dan keyakinan setiap agama. Paham yang ketiga ini dianggap sebagai pucuk dari sikap keberagamaan umat manusia. Sikap inilah yang dipercaya dapat mewujudkan kerukunan dan ketenteraman di antara umat beragama. (Hick, 1987)

Agama membawa manusia pada kehidupan yang bernuansa pluralis, kata pluralisme sendiri memiliki makna dan bentuk yang luas. Ada beragam bentuk pluralisme, seperti pluralisme budaya, pluralisme sosial, pluralism ekonomi, dan pluralisme hukum. (Naim, 2014, p. 9) Pluralisme dalam bahasa Inggris pluralism, terdiri dari dua kata plural sama dengan "beragam" dan isme sama dengan "paham" yang berarti beragam pemahaman. (https://id.wikipedia.org/wiki/Pluralisme, 2021) Sedangkan Agama sendiri secara etimologi, "agama" berasal dari bahasa sanskerta yang menunjuk kepada sistem kepercayaan dalam Hinduisme dan Buddhisme di India. Agama terdiri dari kata "a" yang berarti "tidak", dan "gama" yang berarti "kacau". Dengan demikian sederhananya berarti aturan atau tatanan untuk mencegah kekacauan dalam kehidupan manusia. (Naim, 2014, p. 3)

Pada dasarnya pluralisme agama adalah sebuah kenyataan bahwa di negara atau daerah tertentu terdapat berbagai pemeluk agama yang hidup 
secara berdampingan. (Husaini, 2005, p. 3) Sebagaimana pernyataan Komarudin Hidayat "Suatu kenyataan yang tidak dapat dibantah bahwa bumi ini hanya satu, sementara penghuninya terkotak-kotak ke dalam berbagai suku, ras, bangsa, profesi, kultural dan agama”. (Saputra, 2012, hal. 2)

Para pencetus gagasan pluralisme agama diantaranya: Pertama, Ernst Troelsch (1865-1923), seorang teolog kristen liberal dalam sebuah makalahnya yang berjudul "posisi agama Kristen di antara agama-agama di dunia" dia berpendapat bahwa dalam semua agama termasuk Kristen selalu mengandung elemen kebenaran mutlak. Konsep tentang ketuhanan dimuka bumi ini beragam tidak hanya satu. Kedua, Willian E. Hocking dalam bukunya Rethinking Mission (1932) dan berikutnya Living Religions and A World Fait memprediksikan munculnya model keyakinan atau agama universal baru yang selaras dengan konsep pemerintahan global. Ketiga, Wilfret Cantwell Smith dalam karyanya Towards A World Theology (1981) karena gagasannya pluralisme semakin berkembang dia meyakinkan perlunya menciptakan konsep teologi universal atau global yang bisa dijadikan pijakan bersama (common ground) bagi agama-agama dunia dalam berinteraksi dan bermasyarakat secara damai dan harmonis. (Thoha, 2005, pp. 11-14)

Pluralisme agama di Indonesia adalah realitas yang tidak bisa dipungkiri, para pendiri bangsa menetapkan negara ini bukan menjadi sebuah negara agama (teokrasi) atau bukan pula negara sekuler (sekuleristik). Pilihannya berada tepat di tengah-tengah antara keduanya yaitu bentuk negara yang berpaham simbiostik. (Ruslan, 2010) Negara simbiostik menjadi faktor penunjang terbangunnya harmoni sosial di tengah-tengah kemajemukan suku, etnis, dan agama. Oleh karena itu, tidak ada agama yang tidak berperan bagi negara, dalam kitab suci, Al-Qur'an mengisyaratkan tentang adanya kemajemukan. Surah Yunus: 99-100 yang berbunyi: 


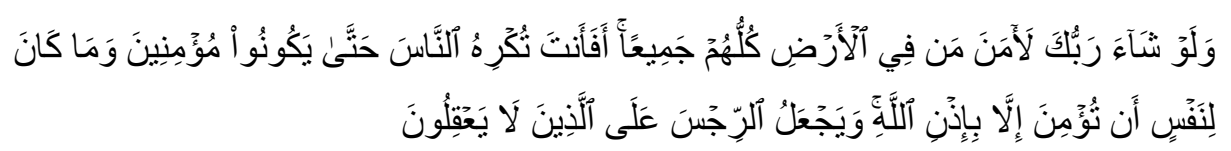

"Dan jikalau Tuhanmu menghendaki, tentulab beriman semua orang yang di muka bumi selurubnya. Maka Apakah kamu (bendake) memaksa manusia supaya mereka menjadi orang-orang yang beriman semuanya? dan tidak ada seorangpun akan beriman kecuali dengan irin Allah; dan Allah menimpakan kemurkaan kepada orang-orang yang tidak mempergunakan akalnya."

Bangsa Indonesia menyimpan berbagai kemajemukan dan keberanekaan, kemajemukan dan keberanekaan ini mewujud dalam pelbagai segi kehidupan dalam bangsa Indonesia yang menempati gugusan kepulauan yang ribuan jumlahnya di satu kawasan yang amat luas wilayahnya, dalam hal ini dibentuk oleh berbagai suku bangsa yang mempunyai adat-istiadat dan bahasa sendiri-sendiri di samping menganut agama yang berbeda-beda. (Ali A. M., 1987, hal. 321) Di tengah-tengah kemajemukan ini terkadang timbul gesekan-gesekan yang melahirkan konflik horizontal yaitu konflik antar umat beragama, seperti kasus konflik agama di Myanmar Rohingya (31 Agustus 2017) yang mengakibatkan terjadi insiden yang sangat memilukan. (Ali A. M., 1987, hal. 12)

Jamaknya pola pikir manusia dalam menganut agama yang berbeda, seseorang telah berani untuk membenarkan atau menyalahkan satu pihak baik itu agama yang dianutnya maupun agama yang tidak dianutnya. Menurut hemat penulis keterbatasan wawasan dan ilmunyalah sehingga seseorang sesuka-sukanya saja mengatakan dialah yang paling benar.

Dalam buku Tuban Semua Agama (Saputra, 2012, p. 4) agama menurut Karl Marx, hanya sebagai candu yang memabukkan dan melenakan. Pernyataan Mark ini tidak begitu membahayakan karena posisinya sangat jelas dalam memahami sebuah agama. Namun, yang paling membahayakan adalah ketika seseorang menggunakan legitimasi agama untuk menghina, 
menganiaya, membunuh orang lain atau berperang (teror) demi memperjuangkan kebenaran agama yang diyakininya.

Berangkat dari kesadaran untuk mempertemukan agama dari tataran esensinya, di mana semua agama mengajarkan pembebasan, artinya tidak ada pemaksaan dalam memeluk sebuah agama, maka fungsi agama bisa diharapkan kembali seperti adanya, yakni mengambil peran pembebasan atas kemanusiaan. Salah satu tokoh pluralisme di Indonesia adalah A. Mukti Ali, beliau lahir di Cepu, 23 Agustus 1923. Mukti Ali adalah alumnus Universitas Islam Indonesia. Beliau juga adalah Menteri Agama RI pada tahun (19711978. Dia juga seorang Guru Besar di IAIN Yogyakarta, dan pernah menjabat sebagai Dekan Fakultas Ushuluddin IAIN Yogyakarta, dan juga seorang staf di sekjen Kementerian Agama. (Handrianto, 50 Tokoh Islam Liberal, 2007, hal. 9)

Menurut Abdul Mukti Ali ada dua aspek agar terbentuknya keharmonisan dalam beragama, yakni aspek keilmuan dan aspek relasi sosial. Dari dua aspek ini Abdul Mukti Ali dengan semangat untuk membudayakan dialog antar umat beragama agar memantapkan keharmonisan sosial dalam kehidupan. (http://jurnal.uinsu.ac.id/index).

Pertama aspek keilmuan, disadari bahwa untuk membangun dan kerja sama antar manusia tentunya diperlukan metode yang tepat dalam memahami kenyataan keberagaman, maka Mukti Ali memperkenalkan dan mengembangkan disiplin ilmu perbandingan agama tersebut dengan kata lain dialog antar agama yang hakiki harus berangkat dari etos saling menghargai dan menghormati. Yang kedua aspek relasi sosial bahwa untuk mewujudkan hubungan sosial yang harmonis maka penting untuk membudayakan dan melaksanakan dialog antar agama sehingga akan menumbuhkan toleransi dalam hubungan antar umat beragama di Indonesia yang sangat plural. 


\section{HASIL DAN PEMBAHASAN}

\section{Biografi Abdul Mukti Ali}

Nama lengkap Abdul Mukti Ali adalah, Prof. Dr. H. Abdul Mukti Ali lahir pada tanggal 23-Agustus-1923 di Cepu, Blora, Jawa Timur. Nama kecilnya Boedjono, ia adalah anak kelima dari tujuh saudara. Ayahnya, Idris, seorang pedagang tembakau yang sukses di kala itu, ayahnya dikenal sebagai seorang donatur yang dermawan, khususnya untuk mendanai kegiatankegiatan keagamaan di kota Cepu. (Azra, 1998, p. 273) Sedangkan ibunya bernama Mutiah namun seusai melaksanakan ibadah haji nama ibunya diubah menjadi Hj. Khodijah, ia adalah seorang saudagar kain pada waktu itu. (http://syaifworld.blogspot.co.id/2016/09/biografi-dan-pemikiran-prof-dr-habdul.html, n.d.)

Pada usia 8 tahun, Boedjono disekolahkan oleh ayahnya di sekolah Belanda, belakangan sekolah itu menjadi HIS pada tahun 1941. Di samping itu, ia juga disekolahkan pada Madrasah Diniah di sore harinya. Di kedua sekolah ini, Boedjono dikenal sebagai seorang siswa yang berprestasi dan bersahaja. Menurut teman-temannya waktu itu, selain ia memperlihatkan nilai mata pelajaran yang gemilang, Boedjono juga dipandang sebagai anak dari sebuah keluarga kaya namun tetap bersikap sederhana. (Azra, 1998, p. 273) Setelah menjalani aktivitas belajar tingkat dasar, delapan tahun kemudian ia menamatkan sekolah HIS, dan Boedjono sendiri telah mendapatkan sertifikat pegawai pemerintah Belanda (Klein Ambtenar Examen) di Cepu. Tidak hanya di tingkat dasar saja, aktivitas atau karir intelektualnya terus meningkat.

Pada pertengahan tahun 1940, Boedjono dikirim oleh ayahnya sendiri untuk melanjutkan dan menimba ilmu pada tingkat menengah yaitu di pondok pesantren Termas di Kediri. Dari pondok Pesantren Termas inilah, tahap lain dari perjalanan hidup Boedjono muda bermula. Ia diterima belajar di tingkat menengah di pondok pesantren ini, Di pondok pesantren, Boedjono tidak hanya belajar seperti biasa saja akan tetapi ia juga diwajibkan 
untuk mengikuti kegiatan mengaji kitab, dengan sistem sorogan (bacaan) atau bedongan (diskusi) yang materinya terdiri dari fiqih, hadits, tasawuf dan akhlak. Dimasa-masa kemudian, Boejono merenungkan bahwa, lewat pendidikan pondok pesantren inilah ia di kemudian hari bisa mengapresiasi khasanah intelektualnya dalam Islam klasik sehingga membentuk dan meluaskan pandangan keagamaannya. (Azra, 1998, p. 274)

Di pondok ini, nama kecil dari Boejono diubah menjadi Abdul Mukti Ali yang berawal dari seorang K.H. Abdul Hamid sebagai pimpinan pondok waktu itu. K.H Abdul Hamid mengatakan bahwa ia ingin mengangkatnya sebagai anak. Karena itu ia meminta agar nama jawanya Boedjono diubah menjadi Abdul Mukti, karena nama ini terlihat lebih Islami. (Azra, 1998, p. 274)

Boedjono dengan gembira menceritakan peristiwa itu kepada orang tuanya. Ayah-ibunya menyambut baik, bahkan dengan senang menambahkan nama keluarganya "Ali" agar ditaruh di belakang namanya menjadi Abdul Mukti Ali. Perubahan nama dari Boedjono menjadi Abdul Mukti Ali ini diiringi syukuran di hadapan sanak keluarga mereka. Semenjak itu atau tepatnya pada tahun 1943. Boedjono resmi namanya diganti menjadi "Abdul Mukti Ali" Abdul Mukti diambil dari pemberian K.H Abdul Hamid, dan “Ali” dari usulan orang tuanya. (Azra, 1998, p. 275)

Tidak hanya di sekolah Termas saja sebagai pendidikan keagamaannya, beberapa pesantren lain juga turut membentuk wawasan keagamaannya seperti pondok pesantren Tebuireng, Rembang yang secara khusus mengajarkan kitab-kitab yang berkaitan dengan ilmu hadist, juga pondok Pesantren Lesem dan Padangan di Jawa Timur. Abdul Mukti Ali pernah bergelut di dunia tarekat, karena keluarga Abdul Mukti Ali sendiri mempunyai tradisi keagaman yang dekat dengan tasawuf karena ayahnya dan kakak tertuanya adalah pengikut jama'ah tarekat Qadiriyah di Cepu, sehingga 
berpengaruh padanya untuk ikut aktif di pengajian tarekat Naqsabandiyah, pada waktu itu dipimpin oleh KH. Hamid Dimyati. (Azra, 1998, hal. 276)

Setelah sekian lama mengamalkan ajaran tarekat itu, KH Dimyati tibatiba menasehatkan agar Abdul Mukti Ali meninggalkan amalan kegiatan tarekatnya, karena ia menganggap Abdul Mukti Ali tidak berbakat untuk menjadi sufi atau menjadi mutasawnif. KH Dimyati mengatakan kepada Abdul Mukti Ali jika ingin memperdalam ilmu agama lebih baik membaca buku Milhaq al-Nadhar-nya al-Gazali dan K.H Dimyati sendiri yang akan mengajarinya. Setelah mendengar penjelasan K.H Dimyati tentang buku itu. Buku Milhaq al-Nadhar, teori tentang analisis, ternyata berisi tentang filsafat logika al-Gazali. Dari situlah terbuka pikirannya untuk menjadikan buku itu sebagai bacaan ngaji tambahan, dari pada aktif di jamaah tarekat (Azyumardi Azra 1998, 276). (Azra, 1998, hal. 276)

Di tengah-tengah pergumulannya dengan pengalaman keagamaannya, selama di Termas (di sekolahnya itu), Mukti Ali dikenal sebagai seorang pemuda yang cakap dalam hal mengorganisasikan kegiatan politik. Ia menjadikan isu-isu politik yang sedang tumbuh pada saat itu sebagai pemicu untuk kegiatan politiknya di pesantren: menyebarnya nasionalisme di awal 1945, masuknya Jepang, berdirinya Masyumi, terbentuknya tentara Hizbullah. Di Termas, Mukti Ali juga membentuk semacam kelompok kecil yang terdiri dari teman-teman dekatnya dimana ia bisa menyampaikan ide-ide politik. Di antara teman-temannya itu adalah dua orang putra K.H. Abdul Hamid yang di kemudian menjadi kolega di dunia politik. (Azra, 1998)

Pada tahun kelima sepanjang kehidupannya di Termas, tepatnya pada tahun 1945, sebagaimana yang dialami setiap pemuda pada akhir masa penjajahan Jepang, Abdul Mukti Ali dan teman-temannya terlibat dalam "pergerakan perjuangan" menentang penjajah. Pergerakan ini diikuti oleh para santri, pelajar sekolah, pegawai rendah, dan guru-guru agama yang berasal dari berbagai desa di Termas. Pada mulanya, gerakan ini adalah 
gerakan anak-anak muda tanpa identitas politik yang jelas. Gerakan ini lebih kepada gerakan politik sipil dalam hal tujuan dan karakternya, namun dengan semangat nasionalisme sebagai ideologinya.

Abdul Mukti Ali sendiri, sebagai pemuda terkemuka di gerakan ini, mengatakan bahwa, pergerakan itu termotivasi oleh komitmen terhadap perjuangan para kiyai, seperti K.H. Hasyim Asy'ari, dalam hal semangat keagamaan dan komitmen terhadap pemimpin nasional mereka, yang gigih memperjuangkan kemerdekaan Hindia Belanda. (Abdurrahman, 1993, hal. 22)

Pondok pesantren Termas didirikan oleh K.H. Abdul Manan pada tahun 1830-1862 dengan sistem pendidikan salafiah (salafi), pondok ini terletak jauh di pelosok desa sehingga pada waktu itu sangat sulit sekali dicapai oleh kendaraan. Pondok ini terkenal dengan ilmu alatnya sehingga kitab-kitab yang berisi ilmu alat sangat dipentingkan. Dan yang menjadi kebanggaan pondok pesantren ini adalah karena keberhasilan putra dari K.H Abdul Manan, yang bernama Muhammad Mahfudh, telah menjadi putra Indonesia yang mengajar di Masjidil Haram, Mekkah, dan diberi gelar Syaikh Muhammad al-Turmusi. (Damammi dkk)

Tahun berikutnya Abdul Mukti Ali menamatkan pondok pesantren di Termas tersebut dan ia sempat terjun ke dunia politik pada waktu itu, yaitu sebagai anggota Dewan Wakil Rakyat pada tahun 1946. Meskipun sudah menjadi tokoh politik tingkat daerah, ia tetap menaruh perhatian dan minat yang besar di dunia intelektual atau akademik. Berangkat dari semasa kecilnya dan setelah belajar di pondok pesantren Termas semuanya itu mendorong keputusannya untuk menjadi mahasiswa di Sekolah Tinggi Islam (STI) di Yogyakarta, yang kemudian sekolah tinggi ini berubah menjadi Universitas Islam Indonesia (UII), pada tahun 1947.

Abdul Mukti Ali diterima sebagai mahasiswa di perguruan tinggi tersebut pada tingkat persiapan pada Fakultas Studi Agama. (Azra, 1998, p. 
278) Di Sekolah Tinggi Islamlah (STI), Abdul Mukti Ali bertemu dan, akhirnya tertarik pada figur dan wawasan keilmuannya K.H Mas Mansur yang sebagai seorang tokoh Muhammadiyah dan dosen yang paling dikagumi di STI waktu itu. Abdul Mukti Ali dibuat kagum karena dengan cara mengajar Kiyai Mas Mansur yang lebih banyak memasukkan wawasan keagamaan baru. Ajaran-ajarannya yang ditafsirnya sedemikian berpengaruh pada Abdul Mukti Ali, sehingga Abdul Mukti Ali memberanikan diri untuk belajar secara pribadi dengannya, lalu ia sering bertemu dengan Kiyai Mas Mansur di rumahnya, dan kemudian, minta supaya diizinkan untuk ikut aktif di Muhammadiyah di Yogyakarta. Maka dengan senang hati, Kiyai Mas Mansur mengajak Abdul Mukti Ali di Muhammadiya, sehingga Abdul Mukti Ali semakin dekat dengan organisasi medernis itu, dan meninggalkan latar belakang dan afiliasi keluarganya yang tradisional di NU. (Azra, 1998, p. 279)

Tetapi, keasyikan belajar di STI itu terhenti akibat kedatangan Belanda ke Yogyakarta. Kemudian dalam perkembangan selanjutnya, berujung pada clash militer antara Indonesia dengan Belanda yaitu pada tahun 1949. Abdul Mukti Ali terpanggil rasa patriotismenya yang kemudian ia lansung terjun ke dalam pertempuran sebagai anggota pasukan tentara Angkatan Perang Sabil (APS) di bawah pimpinan KH. Abdurrahman dari Kedungbanteng. Bulan bulan pertempuran di Yogyakarta itu sangat berpengaruh pada kehidupan Abdul Mukti Ali, dirasakan semangat yang berkobar, baik sebelum maupun ketika setelah perang. Sehingga pertempuran itu akhirnya menjadi kilas balik dalam sejarah Indonesia dengan kemerdekaannya. (Azra, 1998, p. 279)

Abdul Mukti Ali juga pernah di Mekkah dan Madinah selama beberapa tahun, bersama adiknya pada tahun 1950. Tidak banyak yang diceritakan oleh Abdul Mukti Ali tentang pengalaman ia selama di Mekkah karena pola kehidupan masyarakat pada waktu itu tidak memiliki pendidikan yang lebih tinggi. Hingga ia pulang dari Mekkah yang belum mencapai lamanya satu tahun tersebut. 
Kemudian ia memutuskan untuk pergi ke Karachi, Pakistan pada tahun 1951 dan ia diterima di program sarjana muda di Fakultas Sastra Arab, Universitas Karachi dengan program Sejarah Islam sebagai bidang spesialisnya. Setelah lima tahun lamanya Abdul Mukti Ali menamatkan programnya di tingkat sarjana muda dan dilanjutkan program Ph.D di Universitas Karachi.

Pada akhirnya Abdul Mukti Ali meneruskan studi di Institute of Islamic Studies, McGill University, Montreal di Kanada, pada tahun 1955 dengan program spesialis Perbandingan Agama. Dan menamatkan program studinya pada tahun 1957, dengan gelar "Master of Arts" dengan judul tesis A Bibliographical Study of Muhammadiyah Movement in Indonesia. Kemudian ia kembali ke Indonesia pada pertengahan tahun 1957.

Tidak hanya itu saja riwayat hidup dari Abdul Mukti Ali ini, tetapi riwayat hidupnya di dunia politik juga pernah beliau rasakan. Karena beliau adalah orang yang berpendidikan tinggi sehingga beliau terpilih sebagai Menteri Agama RI. Waktu itu. Tepatnya pada tanggal 11 September 1971 Abdul Mukti Ali dilantik menjadi Menteri Agama beberapa bulan setelah pemilu. Abdul Mukti Ali menggantikan K.H. Muhammad Dachlan, Menteri Agama dari NU (Nahdatul Ulama') pada Kabinet Pembangunan I pada tahun 1968, yang belum habis masa jabatannya. Karir Abdul Mukti Ali justru tidak diawali dari kegiatan berpolitik saja, akan tetapi dari dunia akademik juga sudah dimulainya, sekembalinya dari belajar di Institute of Islamic Studies, McGiII University, Montreal, Kanada, pada tahun 1957 Mukti Ali sudah dipercaya untuk mengajar di Akademi Dinas Ilmu Agama-agama (ADIA) di Jakarta, dan Perguruan Tingi Agama Islam Negeri (PTAIN), di Yogyakarta. (Azra, 1998, p. 284)

Dalam kaitan ini, prestasi utama Mukti Ali terletak pada peran yang ia mainkan dalam reorientasi politis kebijakan Departemen Agama dengan membangkitkan kegairahan kehidupan beragama dan memperbaiki citra 
lembaga-lembaga keagamaan. Kemudian Abdul Mukti Ali mengakhiri jabatannya sebagai Menteri Agama menyusul terbentuknya Kabinet Pembangunan II pada tahun 1978-1982. Pada periode ini tidak jelas mengapa nama Abdul Mukti Ali tidak tercantum dalam pembentukan susunan Kabinet yang baru, dan posisinya diganti oleh Alamsjah Ratu Perwiranegara ia adalah seorang perwira AD yang sejauh itu merupakan orang ABRI pertama kali memimpin Departemen Agama. Hingga akhirnya Abdul Mukti Ali menghembus nafas terakhirnya pada tanggal 5 Mei 2004 sekitar pukul 17:30 di Rumah Sakit Umum DR. Sardjito, Yogyakarta dalam usia 81 tahun. Ia meninggalkan seorang istri, tiga orang anak dan empat orang cucu. (Handrianto, 50 Tokoh Islam Liberal, 2007, p. 15)

\section{Gagasan dan Pemikiran}

Abdul Mukti Ali lahir dari keluarga yang kaya, karena ayahnya sendiri adalah seorang pedagang tembakau yang cukup sukses di kala itu, lahir dari ayah yang bernama Idris, yang memiliki tingkat pendidikan sangat rendah pada waktu itu, yang diperoleh ayahnya hanya dari mengaji kitab di pesantren di Cepu, tetapi Idris adalah orang tua yang dengan keras menyuruh anaknya untuk sekolah. Sehingga Abdul Mukti Ali dengan semangat intelektualnya bisa melebihi dari ayahnya. Abdul Mukti Ali sebagai seorang tokoh pluralisme yang dilatarbelakangi dari pendidikan pesantren dan melanjutkan kuliah di McGill Montreal yang mengambil prodi spesialis Perbandingan Agama itu, ia juga dikenal sebagai pendekar multikultural-plural dan demokratis, yang mempunyai peran penting dalam pengembangan pemikiran Islam.

Sebagai seorang pemikir, Abdul Mukti Ali terlibat secara khusus dalam pergumulan atau kelompok pemikir. Basis pemikiran keislaman berakar pada tradisi keilmuan klasik yang sangat kuat, dengan kombinasi wawasan dan khazanah pemikiran modern yang sangat kaya. Mukti Ali tercatat memiliki kegiatan organisasi baik dalam maupun luar negeri, pemerintah maupun swasta, dalam bidang kebudayaan, kemanusiaan serta bidang keilmuan. 
Berbagai macam pengalaman keorganisasian antara lain, ia menjadi anggota Komite Kebudayaan Islam, yang berpusat di Paris, menjadi anggota Dewan Penasehat Pembentukan Parlemen Agama-agama Sedunia di New York. Dan masih banyak pengalaman keorganisasian yang lain, yang menjadi tempat bagi Mukti Ali dalam menyampaikan gagasannya menyangkut beragam hal, termasuk diantaranya menata hubungan antar pemeluk agama, yang harmonis dan mengedepankan kedamaian. (Basuki, 2013, p. 32)

Agar terciptanya masyarakat yang harmonis di tengah tengah keberagaman bangsa Indonesia ini Abdul Mukti Ali mengajak untuk saling harga-menghargai dan menciptakan tempat untuk berdialog antar umat beragama sehingga tidak terjadi kesimpangsiuran atau kesalah pahaman di tengah-tengah masyarakat yang beragam ini terlebih keberagaman agama tersebut.

Menurut Abdul Mukti Ali dalam menegakkan kerukunan antar umat beragama di Indonesia, paling tidak menyentuh dua aspek, yaitu aspek keilmuan dan aspek relasi sosial. Pada aspek keilmuan ditandai dengan tampilnya Perbandingan Agama sebagai ilmu pengetahuan yang begitu penting untuk memahami dan menyikapi keragaman agama. Dan juga sebagai sarana untuk menciptakan interaksi yang dinamis antar pemeluk agama. Sementara itu, aspek pada relasi sosial tercermin pada konsep yang sarat makna agree in disagreement (setuju dalam perbedaan) serta dialog antar agama sebagai upaya menciptakan semangat bekerjasama antar umat beragama. (Rambe, 2016)

Menurut penulis sendiri gagasan Abdul Mukti Ali sesuai dengan apa yang diserukan di dalam Al-Qur'an yang mana artinya adalah: Bagimu agamamu, dan bagiku agamaku. QS: Al-Kafirun, ayat 6. Artinya, bahwa tidak ada keterpaksaan dalam memeluk suatu agama dan tidak boleh menyalahkan agama agama yang ada di kalangan kita sendiri, karena akan berdampak buruk kepada hubungan sosial di kalangan masyarakat. Maka dari itu yang perlu 
dicapai di dalam suatu keberagaman adalah agar bisa saling memahami, mengerti dan saling menghargai terhadap perbedaan, dan juga mempererat hubungan sosial antar umat beragama di masyarakat.

Karakter Mukti Ali yang menonjol ketika menyampaikan ide dan pemikirannya adalah tegas namun tetap santun, bersedia menghargai pendapat orang lain, tidak konfrontatif dengan pihak yang menolak idenya, cenderung mencari kompromi atau jalan tengah atas pandangan atau paham yang berbeda serta tidak provokatif. Dengan keahliannya di bidang ilmu agama serta perhatiannya dalam berbagai forum dialog antarumat beragama, Abdul Mukti Ali dianggap sebagai orang yang paling kompeten mengemban maksud tersebut.

Abdul Mukti Ali sendiri berpandangan bahwa perbedaan pemikiran, agama, ras, suku, bahasa dan budaya harus dijadikan sebagai pedoman bersama dalam kehidupan masyarakat. Ditengah perbedaan tersebut, semua kalangan harus menghargai dan menerima pluralisme sebagai kenyataan sosial. Hal ini yang menurut Mukti Ali sangat jarang dilakukan oleh masyarakat Indonesia. Berdasarkan argumentasi tersebut, Mukti Ali secara intensif mengembangkan Ilmu Perbandingan Agama di Indonesia, sebagai sarana keilmuan untuk memunculkan sikap yang inklusif. Disamping itu, Mukti Ali dengan penuh semangat untuk membudayakan dialog antarumat beragama, yang diharapkan mampu untuk menetapkan keharmonisan sosial. (Ali H. , Ilmu Perbandingan Agama, Sebuah Pembahasan tentang Metode dan Sistem, 1965, p. 7)

\section{Pluralisme Agama Abdul Mukti Ali}

Sebagai seorang tokoh cendikiawan muslim Indonesia Abdul Mukti Ali terkenal dengan keharmonisan dalam beragama, sosial, dan bermasyarakat. Mukti Ali sendiri menuntut kepada masyarakat Indonesia agar di dalam bangsa yang multikultural ini harus saling menghargai dan menghormati antara yang satu dengan yang lain baik dalam aspek sosial, politik, ekonomi, 
suku, etnis, dan yang terutama adalah dalam aspek agama. Karena jika hidup ini dijalani tanpa keharmonisan dan tanpa saling menghargai atau menghormati maka Negara Kesatuan Republik Indonesia ini tidak akan pernah terbentuk sebelumnya dan yang terjadi adalah perpecahan antar suku, politik, etnis, budaya, dan agama.

Dalam usaha membangun negara dan membina bangsa dewasa ini kita harus berusaha menemukan keseimbangan antara ilmu dengan agama, antara yang tidak mutlak dengan Yang Mutlak, dan antara akal dengan kesadaran transendental. Dalam nada yang sama, C.A. van Peursen, Guru besar Filsafat Universitas Leiden, menyatakan bahwa dewasa ini kesatuan ketiga nilai kehidupan tidak lagi terjaga, yaitu nilai kebenaran, kesusilaan, dan keindahan. Cerai-berainya kesatuan nilai sebagai pedoman ini mengakibatkan keutuhan hidup seluruhan manusia akan menjadi sulit sekali. (Ali H. , beberapa Persoalan Agama Dewasa ini, 1981, p. 275)

Wacana pluralisme secara umum tidak hanya muncul disebabkan oleh adanya kemajemukan (pluralitas) masyarakat, adanya keanekaragaman dalam berbagai bidang kehidupan serta struktur masyarakat yang terdiri atas berbagai suku dan agama. Lebih dari itu, dalam realitas keragaman tersebut yang lebih penting adalah membangun hubungan sejati kebhinekaan dalam ikatan-ikatan kemajemukan.

Secara prinsip, ada beberapa hal mendasar yang perlu dipertegas berkaitan dengan pluralisme agama. Pertama, pluralisme agama memiliki tujuan terciptanya harmoni. Pemahaman secara objektif terhadap realitas keagamaan bukan bertujuan untuk menyatukan (unity) terhadap keragaman tersebut, sebab keberagaman merupakan usaha untuk mereduksi identitas yang unik dari masing-masing agama sekaligus mengingkari realitas yang memang beragam. Kedua, pluralisme agama berikhtiar untuk mencari dimensi yang memungkinkan terciptanya konvergensi bukan konsensus. Dan 
ketiga, pluralisme agama itu mengedepankan kepercayaan (trust), bukan persetujuan (agreement). (Naim, 2014, p. 15)

Keberagaman adalah realitas yang tidak mungkin untuk ditolak, perbedaan itu sudah pasti ada dan menjadi bagian dari kehidupan sehari-hari, juga sudah menjadi salah satu hal yang mewarnai dunia dewasa ini. Bahkan manusia hidup dalam pluralisme dan merupakan bagian dari pluralisme itu sendiri, baik secara pasif maupun secara aktif, dan tidak terkecuali dalam hal keagamaan.

Menurut Abdul Mukti Ali secara sosiologis, pluralisme agama adalah suatu kenyataan bahwa kita adalah berbeda-beda, beragam dan plural dalam hal beragama, ini adalah kenyataan sosial, sesuatu yang niscaya dan tidak dapat dipungkiri lagi. Dalam kenyataan sosial, kita telah memeluk agama yang berbeda-beda. (Husain, 2014)

Dalam konsep pemikiran Abdul Mukti Ali ada beberapa hal yang sangat penting kita ketahui dalam kehidupan bersosial, bermasyarakat, dan beragama: Pertama, pentingnya menjaga kerukunan antar umat seagama. Umat satu agama memiliki berbagai kelompok yang memiliki perbedaan, misalnya dalam Islam setidaknya ada empat mazhab besar, Islam di Indonesia juga terdiri dari Muhammadiyah, NU, Masyumi, DDII, dan sebagainya. Begitu pula umat agama non Islam yang memiliki perbedaan dalam satu tubuh. Jika perbedaan dalam satu agama ini tidak dikelola dengan baik, bukan tidak mungkin potensi tersebut berubah menjadi konflik. Seperti yang terjadi beberapa tahun terakhir ini dalam tubuh umat Islam, bahkan intern ormas Islam-pun bisa terjadi bentrok antar kubu. Kedua, pentingnya menjaga kerukunan antar umat berbeda agama. Dalam sejarah, konflik agama di belahan bumi manapun pernah terjadi, tak terkecuali di negeri kita yang beberapa dasawarsa lalu sempat mengundang decak kagum dunia karena keberhasilannya mengelola kebhinekaan dalam semangat persatuan. Namun belakangan, konflik Ambon dan Poso adalah contoh nyata dari gagalnya 
pemerintah dan umat beragama mewujudkan poin kedua ini. Ketiga, pentingnya membina hubungan umat beragama dengan pemerintah, agar kehidupan beragama dapat dilaksanakan dengan perasaan damai dan terjamin. Berkaitan dengan hal ini Mukti Ali juga menyatakan bahwa Negara Indonesia bukanlah negara teokrasi dan bukan pula sekuler. (Husain, 2014)

Sebagaimana yang dikemukakan oleh M. Rasjidi, sebagai Menteri Agama Republik Indonesia yang pertama yang diangkat pada tanggal 3 Januari 1946 dan Ketua Diplomatik pertama RI yang mengikuti utusan diplomat Mesir. Bahwa agama adalah integrasi wujud kita yang berkepingkeping kepada kesatuan, kebebasan Ilahi yang menjadi sumbernya, juga partisipasi dalam hukum sebagai tujuan, dan juga suatu masyarakat yang universal seperti yang disebutkan dalam Q.S Yunus ayat 19. (Rasjidi, 1982, p. 52) Di lain sumber juga dijelaskan, yaitu: masalah yang tidak dapat ditawartawar, apalagi berganti, ia mengibaratkan agama bukan sebagai rumah atau pakaian yang kalau perlu dapat diganti. Jika seseorang memeluk keyakinan, maka keyakinan itu tidak dapat pisah darinya. Berdasarkan keyakinan inilah menurut Rasjidi, umat beragama sulit berbicara objektif dalam soal keagamaan, karena manusia dalam keadaan involved (terlibat). Sebagai seorang muslim misalnya, ia menyadari sepenuhnya bahwa ia involved (terlibat) dengan Islam. Namun, Rasjidi mengakui bahwa dalam kenyataan sejarah masyarakat adalah multi komplit yang mengandung religious pluralism, bermacam macam agama, hal ini adalah realitas, karena itu mau tidak mau kita harus menyesuaikan diri dengan mengakui adanya religious pluralisme dalam masyarakat Indonesia. (Husain, 2014, p. 108)

Artinya Rasjidi tidak memandang adanya pertemuan dalam masalahmasalah teologis, pandangan pluralismenya bukan berarti adanya pertemuan dalam hal keimanan. Namun pandangan tersebut hanya merupakan pengakuan atas keberadaan agama-agama lain. Pandangan pluralismenya tidak sampai masuk pada perbincangan tentang kebenaran-kebenaran yang 
ada di dalam agama lain. Pengakuan pluralisme secara sosiologis ini sama maksud dan tujuannya dengan yang dikemukakan oleh Abdul Mukti Ali, yaitu Abdul Mukti Ali secara sosial tidak mempersoalkan adanya pluralisme dalam pengakuan-pengakuan sosial, tetapi ia sangat tegas dalam hal-hal teologis. Ia menegaskan bahwa keyakinan terhadap hal-hal teologis tidak bisa dipakai hukum kompromistis. Oleh karena itu, dalam satu persoalan (objek) yang sama, masing-masing pemeluk agama memiliki sudut pandang yang berbedabeda, misalnya pandangan tentang al-Qur'an, Bibel, Nabi Muhammad, Yesus dan Mariam. (Husain, 2014, p. 109)

Lain halnya menurut M. Amin Abdullah, ia adalah seorang filsuf, ilmuwan, pakar hermeneutika dan cendekiawan muslim Indonesia, sebagai Rektor Universitas Islam Negeri Sunan Kalijaga Yogyakarta dan aktivis Muhammadiyah dengan jabatan tertinggi sebagai Wakil Ketua Pimpinan Pusat Muhammadiyah tahun 2000-2005. Bahwa pluralisme agama merupakan sebuah keniscayaan dan sekaligus sebuah kebutuhan. Baginya manusia tidak mungkin menghilangkan pluralisme yang telah diciptakan oleh Tuhan, pluralisme agama dan dialog antar umat beragama adalah persoalan klasik yang dihadapi oleh umat Islam. Kemudian dalam kerangka membangun pemahaman dan kesadaran terhadap pluralisme agama M. Amin Abdullah menawarkan berbagai langkah, mulai dari aspek yang sifatnya filosofis hingga aspek yang praktis. Baginya dialog menjadi kunci penting yang tidak bisa diabaikan dalam mewujudkan idealitas, ia pun menyadari bahwa dialog antar umat beragama telah banyak dilakukan dalam berbagai bentuk, peran pentingnya adalah pemerintah dalam hal ini yang dimaksud adalah Kementerian Agama yang kemudian diikuti oleh berbagai organisasi sosial keagamaan. (Naim, 2014, p. 49)

Abdul Mukti Ali menegaskan bahwa masing-masing agama memiliki keyakinan teologis yang tidak bisa dikompromikan. Islam memiliki keimanan sendiri, bahkan termasuk mengenai hal-hal yang diyakini oleh umat agama 
lain, misalnya konsep tentang Nabi Isa. Begitu juga, Kristen memiliki keimanan sendiri, bahkan termasuk mengenai hal-hal yang diyakini oleh Islam, misalnya konsep tentang Nabi Muhammad. Jadi, pengakuan tentang pluralismenya berada pada tataran sosial, yakni bahwa secara sosiologis kita memiliki keimanan dan keyakinan masing-masing. Persoalan kebenaran adalah persoalan dalam wilayah masing-masing agama. (Husain, 2014, p. 109)

Dalam realitas beragama menurut Abdul Mukti Ali ada tiga unsur penelitian agama yang harus ditempuh, yaitu:

Pertama, Refleksi Agamis Refleksi Agamis yaitu refleksi atas iman sendiri dan refleksi dalam iman. Dalam hal ini beriman adalah berkeyakinan yang diikuti dengan perbuatan yang sesuai dengan keyakinan itu. (Ali H. , beberapa Persoalan Agama Dewasa ini, 1981, p. 329) Artinya adalah setiap perbuatan atau tingkah laku yang dipraktekkan oleh seseorang itu adalah atas dasar kepercayaan dia terhadap sesuatu. Memang manusia dalam diri pribadinya sendiri mempunyai kebutuhan-kebutuhan agamis dan mungkin cenderung untuk mencari yang Ilahi, tetapi untuk sungguh-sungguh beriman harus lewat orang-orang yang beriman terlebih dahulu.

Bagi Abdul Mukti Ali hidup beragama itu tidak hanya hidup bathin saja melainkan hidup yang berpangkal pada kepercayaan terhadap agama yang diyakini serta penerapannya dalam kehidupan sehari-hari sesuai dengan ucapan batinnya. Memang manusia dalam diri pribadinya sendiri mempunyai kebutuhan-kebutuhan agamis dan munkin cenderung untuk mencari yang Ilahi, tetapi untuk sungguh-sungguh beriman harus lewat orang-orang yang beriman terlebih dahulu. (Ali H. , beberapa Persoalan Agama Dewasa ini, 1981, hal. 329)

Kedua, Pengungkapan Iman dalam Situasi Konkret. Pada umumnya setiap manusia memiliki agama dan kepercayaan tersendiri dalam kehidupan yang ia tempuh. Agama sebagai refleksi iman yang tidak hanya terbukti dalam ucapan keyakinan dan iman saja, tetapi agama juga merefleksikan 
sejauh mana iman itu diungkapkan dalam kehidupan dunia ini. Iman tanpa perwujudan amal itu hanya menghasilkan nilai kosong atau nihil dan tidak memberikan dampak apa-apa. Bagi Abdul Mukti Ali penelitian agama yang perlu digarap adalah (pertama) mengamati fakta-fakta (kedua) menentukan dimana letak kemungkinan-kemungkinan yang menonjol (ketiga) berdasarkan pemahaman yang rasional. (Ali H. , beberapa Persoalan Agama Dewasa ini, 1981, p. 329)

Ketiga, Sikap Agamis dalam Penelitian Situasi Konkret Kaum Agama. Dalam rangka melakukan penelitian agama itu perlu ditekankan beberapa unsur dan harus diatur dengan sedemikian rupa sehingga seluruh pendekatan empiris diwarnainya. Karena bidang agama dalam manusia begitu bersifat pribadi dan dalam, sehingga harus diamati dengan hati-hati. Jika seorang peneliti yang secara teknis mungkin sangat baik itu belum pasti dapat menemukan persoalan-persoalan agamis pada orang yang diwawancarai atau diteliti, kecuali kalau ia sendiri yang beriman dan reflektif, dalam hal ini bukan saja pada situasi sementara melakukan penelitian itu tetapi juga di luar konteks penelitian yaitu dalam kehidupan sehari-hari. (Ali H., beberapa Persoalan Agama Dewasa ini, 1981, p. 331)

Dari ketiga unsur yang telah ditekankan oleh Abdul Mukti Ali pada hakikatnya itu bertumpu dalam kehidupan sosial, kemasyarakatan, dan agama. Unsur-unsur tersebut patut dan perlu diteliti sehingga dapat menghasilkan dan menimbulkan suatu hal yang baru dalam problem-problem keagamaan, maka dari hal yang baru itulah kita dapat mencari titik temu sebuah problem dalam beragam macam agama tersebut. Dalam perspektif Komaruddin Hidayat, adalah Rektor Universitas Islam Negeri Syarif Hidayatullah Jakarta periode 2006-2010 dan 2010-2015. Bahwa ia tidak berpandangan bahwa semua agama itu sama dan identik, tetapi setidaknya memberi ruang pengakuan dan penghargaan adanya kebenaran pada agama lain. Ini bukan sebuah kesesatan yang buruk, melainkan sebagiannya merupakan keharusan 
penjelmaan historis dari hakikat agama yang esoterik, dan bukan berarti pluralisme sebagai relativis yang tidak memiliki pendirian. Kecenderungan melihat perbedaan juga tidak perlu disalahkan karena setiap orang beriman senantiasa ingin mencari, menggenggam, dan membela kebenaran yang diyakininya berdasarkan pengetahuan dan adat istiadat yang diyakininya. Karena baginya orang yang beragama secara dewasa akan menghayati kebenaran agamanya dan tidak menyalahkan agama yang lain. (Naim, 2014, pp. 53-54)

Azyumardi Azra juga mengemukakan pendapat tentang pluralisme agama, ia adalah Akademisi Muslim asal Indonesia dan pernah menjadi Rektor UIN Syarif Hidayatullah sejak tahun 1998-2006. Menurutnya, dia sendiri mendukung pluralisme. Bagi Azra pluralisme diakui oleh Islam dalam kerangka normatif dan historis. Oleh karena itu, usaha atau upaya untuk menciptakan sebuah masyarakat yang tidak plural, masyarakat yang monolitik, atau masyarakat yang tunggal, itu merupakan upaya yang sia-sia. Maka dari itu sikap yang paling tepat adalah dengan mengembangkan sikap saling menghormati, menghargai, dan toleran dalam perbedaan. (Naim, 2014, p. 56)

Dari berbagai argumentasi para tokoh-tokoh pluralis diatas bahwa keberagaman sudah barang pasti ada, dan keberagaman tersebut tidak bisa dielakkan lagi. Namun yang yang paling penting para penganut agama ketahui adalah bahwa mereka harus menerima keberagaman tersebut dengan lapang dada dan mengakui bahwa setiap agama memiliki realisasi iman tersendiri. Tuhan menciptakan keberagaman ini dengan penuh hikmah dan sangat bermakna dalam artian sangat perlu dipahami dan dimengerti oleh setiap penganut agama tentang keberagaman (pluralisme) tersebut, dari keberagaman itu pula kita bisa mengetahui banyak hal, seperti pengalaman beragama, ilmu-ilmu agama, dan ilmu-ilmu dalam bersosial, dari beragama macam agama tersebut. 
Penulis sendiri mengharuskan, di dalam pluralisme, para penganut agama diminta agar hatinya tulus (ketulusan hati) untuk mengakui sekaligus memelihara, dan mengembangkan, atau memperkaya keadaan yang plural, jamak, atau banyak. Selain daripada itu para penganut agama juga harus saling menghargai, menghormati dalam kehidupan bermasyarakat, bersosial, terutama beragama. Jika tidak terciptanya hubungan antarumat beragama yang baik, harmonis, toleran, saling menghormati dan menghargai maka pada umumnya tidak akan terbentuk dan terciptanya negara Republik Indonesia ini dengan sedemikian rupa.

Pluralisme agama adalah kehendak mutlak Tuhan maka realitas seperti ini adalah hal yang urgen untuk dikedepankan ide-ide konvergensi agamaagama. Yaitu suatu usaha untuk mencari titik temu dari pada agama-agama. Dalam doktrin Islam usaha ini memperoleh legitimasi atau penguat teologis lewat kitab suci Al-Qur'an. Di dalamnya tersirat secara tegas bahwa termaktub dalam Al-Qur'an titik temu agama-agama yang diistilahkan dengan kalimatun sawa yaitu titik temu agama-agama. (http:// digilib.uinsby.ac.id/4241/7/Bab\%203.pdf)

Pada abad ke-18 M yang disebut masa pencerahan, adalah sebagai titik permulaan bangkitnya gerakan pemikiran modern di Eropa. Meskipun pemikiran pluralisme agama telah mewarnai Eropa pada saat itu. Baru pada abad ke-20 pemikiran pluralisme agama mengakar secara kokoh dalam wacana pemikiran Filsafat Teologi Barat. Abdul Mukti Ali mengungkapkan bahwa agama adalah sebagai pemberi petunjuk agar moral dapat dijalankan, agamalah yang harus memberikan hukum-hukum moral karena agama merupakan sanksi yang terakhir dari semua tindakan moral. (Ali H. Beberapa Persoalan Agama Dewasa ini, 1981, hal. 266) Pada dasarnya setiap ajaran agama memiliki nilai-nilai universal karena tidak satu agama pun yang mengajarkan dan memerintahkan pemeluknya untuk berbuat jahat, berlaku tidak adil, bermusuhan, dan lain-lain. Oleh karena itu, dari nilai universal ini, 
tiap-tiap pemeluk agama memiliki keinginan bersama untuk hidup berdampingan tanpa permusuhan, juga, memiliki misi yang sama untuk membangun peradaban dunia atas dasar nilai-nilai agama yang universal itu. (http://digilib.uinsby.ac.id/4241/7/Bab\%203.pdf).

Bagi Harun Nasution agama dapat diberi definisi sebagai: pertama Pengakuan terhadap adanya hubungan manusia dengan kekuatan gaib yang harus dipatuhi. Kedua Pengakuan terhadap adanya kekuatan gaib yang menguasai manusia. Ketiga Mengikatkan diri pada suatu bentuk hidup yang mengandung pengakuan pada suatu sumber yang berada di luar diri manusia dan yang memengaruhi perbuatan-perbuatan manusia. Keempat Kepercayaan pada sesuatu kekuatan gaib yang menimbulkan cara hidup tertentu. Kelima Adalah suatu sistem tingkah laku yang berasal dari suatu kekuatan gaib. Keenam Pengakuan terhadap adanya kewajiban-kewajiban yang diyakini yang bersumber pada suatu kekuatan gaib. Ketujuh Pemujaan terhadap kekuatan gaib yang timbul dari perasaan lemah dan perasaan takut terhadap kekuatan misterius yang terdapat dalam alam sekitar manusia. Kedelapan Ajaran ajaran yang diwahyukan Tuhan kepada manusia melalui seorang rasul. (Naim, 2014, p. 4)

Berbeda dengan argumentasi yang dijelaskan oleh Nasr, menurutnya bahwa setiap agama memiliki satu bentuk dan satu substansi. Substansi mempunyai hak-hak yang tidak terbatas, karena ia lahir dari yang Mutlak, sedangkan bentuk adalah relatif, maka hak-haknya terbatas. (Husain, 2014, p. 101) Agama sendiri dibatasi oleh bentuk-bentuknya maka agama tersebut bersifat relatif. Dalam hal ini sangat dipengaruhi oleh keterbatasan manusia untuk mengungkapkan hal yang absolut tersebut.

Untuk mencapai kerukunan dalam kehidupan beragama bahwa ada lima aspek pemikiran yang penting untuk dikemukakan yaitu: (Ali $\mathrm{H}$, Memahami Beberapa Aspek Ajaran Islam, 1991, pp. 56-60) 
Pertama Sinkretisme, yaitu pendapat yang menyatakan bahwa semua agama adalah sama. Maksudnya adalah berbagai-bagai aliran dan gejala-gejala yang hendak mencampur-baurkan segala agama menjadi satu dan menyatakan bahwa semua agama pada hakikatnya sama. Sehingga orang berpandangan jika suatu agama muncul atau tercipta dari Zat yang sama maka tujuan dan maksudnya pun sama dalam aspek pengabdian kepada zat tersebut. Kedua Reconception, yaitu menyelami dan meninjau kembali agama sendiri dalam konfrontasi dengan agama-agama lain. Maksudnya adalah kita sendiri harus mengkaji lebih dalam lagi agama yang kita peluk (masing-masing pemeluk agama), tanpa terlebih dahulu untuk mengklaim bahwa agama yang ia peluklah yang paling benar dari berbagai macam agama-agama yang ada di muka bumi ini. Ketiga sintesis, yaitu menciptakan suatu agama baru yang elemen-elemennya diambilkan dari pelbagai agama, supaya dengan demikian tiap-tiap pemeluk agama merasa bahwa sebagian dari ajaran agamanya telah terambil dalam agama sintesis (campuran) itu. Keempat penggantian, yaitu mengakui bahwa agamanya sendiri itulah yang benar, sedang agama-agama lain adalah salah, dan berusaha supaya orang-orang yang lain agama masuk dalam agamanya. Mereka tidak sudi bahwa ada agama yang berlainnan dengan agamanya, agama-agama yang hidup harus diganti dengan agama yang ia peluk, maka dengan itu ia baru merasa bahwa kerukunan hidup beragama baru dapat tercipta. Kelima Agree in disagreement (setuju dalam perbedaan), yaitu percaya bahwa agama yang dipeluk itulah agama yang paling baik, dan mempersilahkan orang lain untuk mempercayai bahwa agama yang dipeluknya adalah agama yang paling baik. Diyakini bahwa antara satu agama dan agama lainnya, selain terdapat perbedaan, juga terdapat persamaan (Ali H., Memahami Beberapa Aspek Ajaran Islam, 1991, p. 56).

Dari kelima aspek di atas ini menurut Abdul Mukti Ali hanya satu aspek yang sesuai dengan pemikirannya yaitu agree in disagreement. Dan inilah alasan beliau kenapa aspek yang lain tidak sesuai dengan pemikirannya, 
pertama aspek "sinkretisme" ini tidak dapat diterima dengan alasannya; dalam ajaran Islam misalnya, Khaliq adalah lain daripada makhluk. Artinya Zat yang menciptakan adalah lain dari yang diciptakan. Aspek yang kedua dengan jalan "reconception" juga tidak dapat diterima, karena dengan jalan itu agama merupakan produk pemikiran manusia, sedangkan pada esensinya agama adalah wahyu. Aspek yang ketiga dengan jalan "sintesis" juga tidak dapat diterimanya, agama sintesis itu sendiri tidak dapat diciptakan, karena tiap-tiap agama mempunyai latar belakang sejarahnya tersendiri yang tidak begitu saja dengan mudah diputuskan. Kemudian aspek yang ke empat yaitu dengan jalan "penggantian" juga tidak dapat diterima oleh Abdul Mukti Ali, karena kita hidup dalam masyarakat serba ganda (plural society), dalam penggantian ini tentu saja tidak akan menimbulkan kerukunan hidup beragama, bahkan bisa menimbulkan intoleransi karena orang akan berusaha dengan segala jalan, apakah itu baik atau buruk untuk menarik orang lain agar mengikuti agama yang ia peluk. Selanjutnya aspek yang ke lima yaitu dengan jalan "agree in disagreement" (setuju dalam perbedaan) bagi Abdul Mukti Ali inilah jalan yang paling baik dan sempurna untuk ditempuh agar terciptanya kerukunan hidup dalam beragama (Ali H., Memahami Beberapa Aspek Ajaran Islam, 1991, p. 61).

Makhluk yang hidup di muka bumi ini tidak satu macam saja, tetapi berbagai macam bentuk yang Allah ciptakan di muka bumi ini mulai yang bergerak sampai ke yang tidak bergerak, mulai dari yang kecil sampai ke yang besar itu semua adalah ciptaan Allah SWT. Akan tetapi ada makhluk yang diciptakan oleh Allah dengan sesempurna mungkin yang memiliki hati (rasa), otak (akal) dan hawa nafsu, yaitu manusia. Allah menciptakan makhluknya tidak lain hanya memiliki satu tujuan saja, yaitu untuk menyembah kepadanya. Nah dalam problem pengabdian diri kepada sang Khaliq inilah manusia memiliki berbagai macam konsep dan berbagai macam cara sesuai dengan keyakinan seseorang kepada sang penciptanya. Namun yang menjadi 
perpecahan, permusuhan, caci maki dalam perbedaan agama ini hanyalah akibat oknum-oknum yang tidak bertanggung jawab atas perbuatannya dengan mengatasnamakan golongan atau agama.

\section{PENUTUP}

Berdasarkan pembahasan di atas penulis menyimpulkan bahwa $\mathrm{H}$. Abdul Mukti Ali sudah melalang buana dan telah banyak menginjakan kakinya di berbagai perguruan tinggi di belahan dunia, berkat dari ketekunan dan kesabaran beliau sampai dimana belau mengabdi pada negara Republik Indonesia dan menjadi menteri agama pertama Republik Indonesia, ini sesuai dengan latar belakang pendidikan beliau yang mana ia banyak belajar dibidang keagamaan (jurusan perbandingan agama) dan sejarah-sejarah agama.

Menurut Abdul Mukti Ali ada dua dasar untuk membina kerukunan hidup umat beragama di Indonesia. Pertama, bersifat filosofis berupa falsafah negara pancasila yang mengandung nilai-nilai dan prinsip-prinsip yang dapat diterima oleh semua pihak dan golongan. Kedua, adalah bersifat pragmatis, yakni tugas nasional dalam rangka pembangunan bangsa dimana semua pihak berkewajiban melaksanakan dan menyukseskannya.

Dari beberapa aspek untuk mencapai kehidupan kerukunan umat beragama, Abdul Mukti Ali memilih yang sejalan dan sesuai dengan pemikiran beliau yaitu agree in disagreement artinya setuju dalam perbedaan. Penulis sendiri berpikir dan menghayati baha pada aspek ini sangan sesuai dan uniknya adalah pada aspek ini bahwa selagi kita berpegang pada dan mengamalkannya (agree in disagreement) maka aspek ini bisa hidup selamanya dan tidak dapat dibantahkan sesuai dengan perkembangan zaman. Inilah yang perlu dan penting kita tanamkan kepada anak-anak bangsa kita, apapun agamanya, sukunya, rasnya, maka tanamkan konsep pluralisme beragama agree in disagreement sehingga keutuhan dan kerukunan bangsa indonesia selalu terjaga. 
Titik temu dalam kerukunan antar umat beragama menurut Abdul Mukti Ali yaitu pada aspek konsep pemikiran "agree in disagreement" (stuju dalam perbedaan). Karena dalam konsep inilah masing-masing agama bisa saling menghormati dan menghargai dalam ritual-ritual atau peribadatan keagamaan. Keberagaman adalah suatu hal yang tidak bisa dihindari oleh manusia, artinya kita sudah seharusnya menerima ketetapan Allah yang telah menciptakan perbedaan-perbedaan di antara manusia itu sendiri, maka dari itu kita sebagai makhluk yang diciptakan oleh Allah dengan kesempurnaan akal pikiran yang harus dilakukan adalah berbuat kebaikan dan saling menghormati dalam menyikapi kemajemukan. Karena yang akan selamat adalah orang yang selalu berbuat kebaikan, yang penulis maksud di sini adalah orang-orang yang tidak mudah menyalahkan orang lain namun tetap lapang dada dalam menyikapi terhadap perbedaan yang ada.

\section{DAFTAR REFERENSI}

Abdurrahman, B. D. (1993). Agama dan Masyarakat: 70 Tabun H. A. Mukti Ali. Yogyakarta: IAIN Sunan Kalijaga Press.

Ali, A. M. (1987). Beberapa Persoalan Agama Dewasa ini. Jakarta: CV. Rajawali. Ali, H. (1965). Ilmu Perbandingan Agama, Sebuah Pembahasan tentang Metode dan Sistem. Yogyakarta: Yayasan Nida.

Ali, H. (1981). beberapa Persoalan Agama Dewasa ini. Jakarta: Rajawali.

Ali, H. (1991). Memahami Beberapa Aspek Ajaran Islam. Bandung: Mizan. Azra, A. (1998). Menteri-menteri Agama RI: Biografi Sosial Politik. Jakarta: PPIM. Basuki, A. (2013). Pemikiran Keagamaan Mukti Ali. 2013: SUKA Press.

Damammi dkk, M. (n.d.). http://digilib.uin-suka.ac.id/id/eprint/12703. Retrieved Januari 2001, from http://digilib.uin-suka.ac.id.

Handrianto, B. (2007). 50 Tokoh Islam Liberal. Jakarta Timur: Hujjah Press. Hick, J. (1987). Religious Pluralism. In M. Eliade, The Encyclopedia of Religion.

New York: Mac Millan Publ. Comp. 
Husaini, A. (2005). Pluralisme Agama: Haram. Jakarta Timur: Pustaka AlKautsar.

Husain, K. (2014). Peran Mukti Ali dalam Pengembangan Toleransi Antar Agama di Indonesia. Jurnal Ushuluddin, XXI(1), 107.

http://jurnal.uinsu.ac.id/index.php/lubb/article/download/516/415. (n.d.). http://jurnal.uinsu.ac.id/index.php/lubb/article/download/516/415.

Retrieved 2021, from http://jurnal.uinsu.ac.id.

http://syaifworld.blogspot.co.id/2016/09/biografi-dan-pemikiran-prof-dr-habdul.html. (n.d.). bttp:/ syaifworld.blogspot.co.id/2016/09/biografi-danpemikiran-prof-dr-h-abdul.html. Retrieved 2021, from http://syaifworld.blogspot.co.id.

http://digilib.uinsby.ac.id/4241/7/Bab\%203.pdf. (n.d.). bttp://digilib.uinsby.ac.id/4241/7/Bab\%203.pdf. Retrieved Januari 2021, from http://digilib.uinsby.ac.id.

https://id.wikipedia.org/wiki/Pluralisme. (2021, Januari 20). https://id.wikipedia.org/wiki/Pluralisme. Retrieved from https://id.wikipedia.org.

Mansur, S. (2018, Juni). Studi Sejarah Agama. JURNAL: AL FATH, 03(01), 18.

Naim, N. (2014). Islam dan Pluralisme Agama. Yogyakarta: Aura Pustaka.

Rambe, T. (2016). Pemikiran A. Mukti Ali dan Kontribusinya terhadap Kerukunan antar Umat Beragama. Jurnal Al-Lubb, 1(1), 24-42.

Rasjidi. (1982). Janji-Janji Islam. 1982: P.T Bulan Bintang.

Ruslan, I. (2010). Etika Islam dan Semangat Pluralisme Agama di Era Global. Al Adyan, V(1), 12.

Saputra, R. (2012). Tuban Semua Agama. Yogyakarta: Lima.

Thoha, A. M. (2005). Tren Pluralisme Agama: Tinjauan Kritis. Depok: Kelompok Gema Insani. 